\title{
ETHNODEMOGRAPHIC SPECIFICATIONS OF XINJIANG (P.R. OF CHINA)
}

\author{
Vladan Grbović ${ }^{* 1}$ \\ * University of Belgrade - Faculty of Geography, Belgrade
}

\begin{abstract}
The paper examines ethnic, demographic, cultural and linguistic aspects of China's Xinjiang Province. It analyzes regional specifications and through causeand-effect explains historical process of formation of different ethnicities and nations, their natural movement, migration and population change, as well as contemporary challenges and tendencies of development.
\end{abstract}

Keywords: China, Xinjiang, Uyghurs, migrations, population.

\section{Introduction}

Xinjiang is a border region of the People's Republic of China where Chinese, Russian and Turkish "worlds" meet. It represents a territory where Chinese dynasties have spread for centuries, and the space where Chinese exists along with Tibetan, Mongolian and Turkic languages. An area where Chinese beliefs of Confucianism and Daoism encounter Tibetan and Mongolian forms of Buddhism, and also with Islam.

The fact that China is a world power often masks the problems such a large country can have. One of them, which is important for Xinjiang, is the complex ethnic structure reflected in the dispersive distribution of people in the area. In addition to the Chinese, the largest Xinjiang national community is the Uyghurs. The fact they are of the Muslim faith is used by competitors of China to problematize this circumstance and then to delocalize it. The Islamic character of the

1 Corresponding author: V. Grbović, University of Belgrade - Faculty of Geography, Belgrade; e-mail: e.vladann@gmail.com 
revolt is intensifying, as are the attempts to join the Uyghurs with other nonTurkic Muslims, with the intention of presenting it as a problem for the entire Islamic world. China has been successfully combating this phenomenon for the time being, but it is far from resolved. All of this threatens China's interests in the Islamic world, from where it mostly supplies with energy.

It is important to note that this movement is not straightforward. Part of the Uyghurs wants to break all ties with China and create an independent state, while the other part wants only a greater degree of autonomy within China (Jevtic, 2011). Some of these problems, as well as potential answers, will be considered in this paper from a historical, ethnographic and demographic perspective.

Natural determinants The autonomous Uyghurian Region of Xinjiang is in northwestern China. In Chinese, it means "New Frontier". It extends 2,000 $\mathrm{km}$ from east to west and 1,650 km from north to south. It has an area of over $1,600,000 \mathrm{~km}^{2}$ and is the largest administrative unit within the People's Republic of China. Measured by time zones, the region is more than two zones away from Beijing ${ }^{2}$.

Xinjiang borders with Mongolia, Afghanistan, Pakistan, India, as well as the three Central Asian states which were a part of the USSR: Kazakhstan, Kyrgyzstan and Tajikistan. Its neighbors within China are Gansu Province, Tibet, and Qinghai. Geographers have classified it as part of the dry "dead heart of Asia," which includes Tibet ${ }^{3}$, Pamir and Mongolia. Conditionally, it can be divided into three parts: the Dzungarian Basin (northern part) - the steppe inhabited predominantly by the Kazakhs and Chinese, the Tarim Basin (southern part) - predominantly inhabited by the Uyghur population, and the Turpan Depression or Hami (east) - with mixed Chinese and Uyghur population (Dillon, 2004).

The vast Taklamakan Desert dominates the Xinjiang area and makes much of the region inaccessible. The southern part of Xinjiang is the "Uyghur heart", mainly a rural society that still lives in oases with traditional agriculture and minimal external influence. To the north is a mountainous area, Tian Shan as Chinese call it, or the "Heavenly Mountains" (in Uyghur - Tengri Tagh, the mountains of God and heaven) in which pastoral nomadism forms an important part of life and tradition. The mountains surround the plains and valleys, and with the Altai Mountains in the north, they form a distinct natural barrier between the eastern part of the Turkic world within China's borders and the much larger western part of the former Soviet Union.

2 With the decision of the authorities, the entire territory of China is in the same hour zone, while informally they also use local time.

3 Tibet has been considered Beijing's main separatist problem since 1949. 


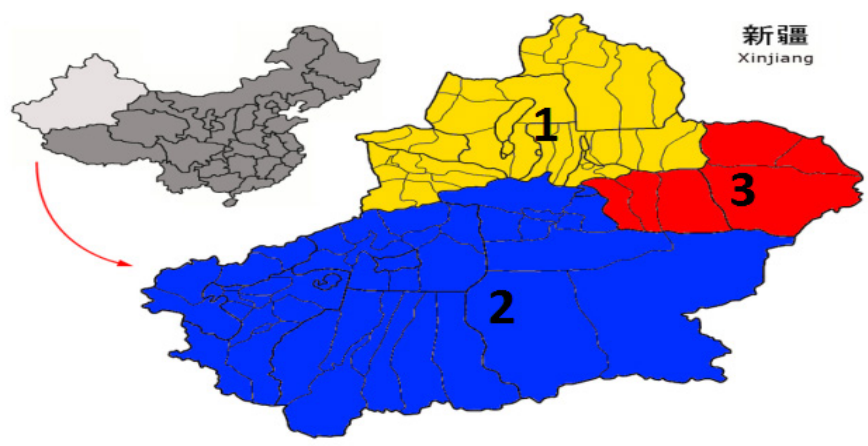

1. Dzungarian Basin

2. Tarim Basin

3. Turpan Depression

Figure 1. Macro Region in Xinjiang

(Source: https://thebetter.wiki/en/Tarim_Basin)

Geographic features such as isolation, water scarcity (a problem it shares with its Central Asian neighbours, but also with regions in China), and not enough arable land - have had a profound impact on the region's history as well as recent economic, demographic and social development.

\section{A historical retrospective}

The first people in history to be called Turkic, lived in the steppes of present-day northern Mongolia. The indigenous people of the region were probably Turkic-speaking people for whose descendants today Uyghurs consider themselves. The history of Chinese relations with Central Asia, of which Xinjiang is an integral part, dates to the Han Dynasty (Fletcher, 1968). It is the first Chinese dynasty to establish influence over the western regions of present-day China (206 BC - 220 AD). Throughout history, Xinjiang has had close contacts with northern India, northern Afghanistan, the Fergana Valley and the Transoxania ${ }^{4}$.

Military raids annexed the territory of the Tarim Basin to Han China, while the Turkic tribes moved west and north of Tian Shan, thus avoiding collision with the Chinese armies (Maljavin, 2008). Migration westward, the Turkic people (historically known as the Huns) continued to Europe, and it is known that they posed one of the greatest threats to the Roman Empire in the $4^{\text {th }}$ and $5^{\text {th }}$ centuries.

In the Medievel period, Chinese power and influence in the region were established during the Tang Dynasty. Their military and economic power dominated Xinjiang from the mid- $7^{\text {th }}$ to mid- $9^{\text {th }}$ century. The Battle of Talas in 751, in present-day Kyrgyzstan, between the Chinese Tang Dynasty and the Arab

4 Region between the Amu and Sir Daria rivers in Central Asia. 
armies, decisively had an impact on which of these two cultures and religions would permanently prevail in Turkestan (Soucek, 2000). The consequences of this defeat were such that the Chinese dynasties never again tried to extend their influence beyond the territory of Xinjiang. Further advances by the Arab forces have been hindered by the geographical barrier of the Tian Shan and Pamir mountain ranges, which still form the border between China and the Central Asian republics of the former Soviet Union.

In subsequent centuries, Central Asia was dominated by the Caliphs of the Omayada Dynasty, and after their fall, the Abbasid Dynasty. In the $10^{\text {th }}$ century, they were succeeded by the Samanid dynasty, when instead of Samarkand, the leading city in the region became Bukhara (in present-day Uzbekistan). The fall of the Tang Dynasty in China made it possible to establish several independent kingdoms of the Turkic tribes, which migrated from present-day Mongolia. These communities of mixed religions were gradually accepting Islam, following the conversion of rulers from the dynasty of Karakhanids, the legendary Satuq Bughra Khan who did the same in 960. Karakhanids (840-1212) consisted of a confederacy of the Turk tribes that ruled the region for centuries (Fuller and Lipman, 2004). It is not possible to determine exactly when Central Asian communities could be recognized as Muslim, but it is most likely that Islam overruled Buddhism (or earlier animalism) before the beginning of $12^{\text {th }}$ century. Most Central Asia and East Turkestan can be regarded as Islamic since mid$14^{\text {th }}$ century, when the city of Kashgar becomes a centre of Islamic religion and culture, which remains to date. In times when Central Asian space is being included in the Chinese or Russian state, the main factor in survival of Islam becomes Sufism ${ }^{5}$.

The next period of significant contacts between China and Central Asia was at the time of Mongolian dynasty of Juan (1234-1368) during which many Central Asian people were in the service of Mongolian rule of China. After the expulsion of Mongol 1368, the Ming dynasty sent numerous missions to Central Asia: to Samarkand, Tashkent, Bouhar, Herat, even Persia (Fletcher, 1968). The Mings, however, did not have enough political will and military forces to reach the conquest of the Mongolian Juan dynasty or the Chinese Tang dynasty, so the region remained outside the sphere of influence of the Ming dynasty (Fletcher, 1968).

Until the time of conquests in China by Mandzurians and the founding of the Qing Dynasty (1644-1911), Central Asia and Xinjiang represented a set of small kingdoms and principalities (Fletcher, 1968). During that period, the Qing Dynasty joined the fight with Russia and the Dzungarian Mongols for dominance in Central Asia, where they eventually established their rule in

5 Sufism is a mystical aspect of Islam whose followers are called Sufis or Dervishes. 
Mongolia, Xinjiang and Tibet. The rulers of the Qing dynasty bring Kazakhs, Uyghurs, Han-Chinese and Hui Muslims ${ }^{6}$ with them, settling them north of Tian Shan. We find the first population data in the time of the Qing Dynasty, when Uyghurs makes up $62 \%$ of the total population, the Chinese (Han and Hui) are about $30 \%$, while $8 \%$ consists of other minorities. At the time, the settlement system was the so-called "twin" system, so that the Chinese and Muslim cities were facing each other.

Chinese settlers were forbidden to settle south of the Tian Shan, while the population of the northern part was continued. The expansion of the Imperial Chinese State in the time of the Qing Dynasty and the expansion of the Imperial Russia into the heart of Central Asia, eventually resulted in the so-called "closure of the steppe", i.e. the integration of large medieval expansions in the powerful empire. While the Army of "foreign" Qing Dynasty was moving toward the west, the influence of the Han-Chinese, their language and culture was gradually spreading. It's proven that was not the intention of the Qing administration on the contrary, there were serious and extensive attempts to put an end to it. During the $18^{\text {th }}$ century a tendency to restrict Chinese migration to newly won territory was particularly expressed. Despite the ban, their migrations in these territories continued (Brophy, 2016).

After the suppression of the Hui Muslim rebellion in Gansu 1873, the government approved the reoccupation of the Xinjiang, so it formally became established as the province in 1884. (Millward \& Perdue, 2004). This period (1813-1917) of the intense rivalry of Britain and Russia in Central Asia is known as the "Great Game". British novelist Rudyard Kipling introduced the term in his novel "Kim" in 1901.

Table 1. Ethnic groups in Xinjiang at the beginning of the 19th century

\begin{tabular}{|l|c|c|}
\hline Ethnic groups & Population & \multicolumn{2}{|c|}{ Percentage } \\
\hline Uyghurs & 320.000 & 62 \\
\hline Chinese & 197.000 & 38 \\
\hline Total & 517.000 & 100 \\
\hline
\end{tabular}

Source: Millward \& Perdue, 2004

The discussion of the Uyghurs nation was a novelty in the early 1920s, and its meaning was often questioned. However, in the mid-30s, Uyghurs received official recognition as a nation. During the $20^{\text {th }}$ century the Uyghurs and the other Turkic people all over the Xinjiang, inspired by Pan-Islamic and Pan-Turkish sentiment, stood up against the Chinese government. They were very divided

6 The Hui people are ethnically belonging to the Chinese who have embraced Islam in the past. They speak the standard Mandarin ("Chinese") language and are still considered a separate nation today. 
among themselves to family, religious and regional fractions, so that no group or individual was able to achieve a single power.

During the period of Republic of China (1912-1949), Xinjiang was under the control of central authorities, with two exceptions. The first secessionist attempt was on November $12^{\text {th }} 1933$ when Turkian-Islamic Republic, East Turkestan was proclaimed, which lasted until February $6^{\text {th }} 1934$. It is indicative that they were defeated by Muslim forces (Hui Muslims), and not the members of the secular Republican forces led by Kuomintang ${ }^{7}$. In many ways, the Republic was a direct heir to the regime of Jaqub Beg, who controlled the region of Kashgar since 1867 until 1877. This continuity is also important for the Uyghur separatists today, because in their short existence they managed to create the government, the Assembly, the Constitution, their own currency and the flag (white star and the crescent with light blue background). In the second attempt, Turkic Muslims and Kazakhs re-establish control and form an Uyghur East-Turkestan Republic which lasted from 1944-1949. This period is known in Chinese history as "Revolution of the three districts". The Uyghur Republic is integrated into the National Republic of China after it was established in 1949. It is important to note that both times during the Japanese occupation, Uyghurs had their state, 1931-1934 and 1944-1949.

In recent history, after the Chinese Civil war', as a sign of appreciation for the Uyghurian people and the fact that their population makes the majority, the Chinese government changes its administrative division in 1955. and Xinjiang becomes an autonomous region. The non- $\mathrm{Han}^{9}$ people of the region and wider, often use East Turkestan as the region's name (in Uyghurian: Sharqi Turkistan), and radical supporters of independence use the term "Uyghuristan" (a term unpopular among the non-Uyghur population of the region). The name Chinese Turkestan was used as well, as an analogy to the Russian Turkestan (a Central Asian States, former member of the USSR and the Russian Empire).

A parameter that can significantly contribute to demographic processes in the region in the future is the fact that China considers Xinjiang as one of the

7 Kuomintang, or the Chinese Nationalist Party, one of the main advocates of the demolition of the Qing dynasty and declaring independence in 1911, which resulted in the establishment of the Republic of China. After the end of Chinese Civil War in 1949 and the founding of the People's Republic of China, Kuomintang is withdrawing to Taiwan where it acts to this day.

8 The Chinese civil war broke out between the Kuomintang (Chinese Nationalist Party) and the Communist Party of China, which lasted from 1927 to 1950 . The war arose as a result of the ideological separation between nationalists supported by the West, and communists supported by the Soviet Union.

9 Han Chinese or "Chinese" are synonymous with the world's largest ethnic community. 
decisive factors in the success of the New Silk Road, which is predicted to be an economic hub that could improve trade and overall relations with neighbouring Central Asia (Mehta, 2018).

\section{Contemporary ethnodemographic processes}

First population research in the $20^{\text {th }}$ century was done by the provincial government of Xinjiang 1940-1941. Considering that 1930s and 1940s were politically unstable, the research accuracy should be taken with some caution. Since 1953 modern census methods were used. The western authors believe the 1964 census was in many ways inadequate and poorly organized, and that due to the Cultural Revolution (1966-1976) only part of the data was processed. It was a time of great turmoil in Xinjiang, so it was not easy to determine levels of fertility, mortality and migration. Census from 1982, 1990, 2000 and 2010 were done according to international standards. It is important to note that the province census does not include the number of military personnel, which often adds to the number of Han-Chinese present.

The main centers of the population concentration are: Ili district (2.1 million), the district of Urumqi (1.5 million) and the county of Changji (1.5 million). The northern belt, covered by the aforementioned districts, accounts for $52.5 \%$ of the total population of Xinjiang. The second belt lies in the south and is defined by a series of oasis in the Tarim Basin. These oasis include Korla, Kucha, Aksu, Artux, Kashgar and Hotan. The most inhabited one is the Kashgarian district (3.2 million), the District of Aksu (2.0 million) and Hotan district (1.6 million). Together, this southern belt makes up $47.5 \%$ of the Xinjiang population. A significant part of the region is recognizable by a very low population density. Because most of the country is made up of deserts or mountainous zones, that leaves a small part of the country that is suitable for agriculture. From the total area of Xinjiang, which is $1,664,900 \mathrm{~km}^{2}$, only $43,500 \mathrm{~km}^{2}(2.6 \%)$ is arable. Only one third of the country is economically usable.

The Xinjiang birth rate is higher than it is in the other parts of China. The most contributing factor to that is the high level of natural assimilation of the non-Chinese population (mostly of Uyghur) and 220,000 new migrants per year (mostly Chinese). High levels of population growth were recorded in the districts of Kashgar (1.5\%), Hotan (1.6\%), Yining (1.4\%), and Urumqi (1.4\%). Low levels of natural population growth are in cities such as Aksu, Kuytun, Shihezi and Urumqi, as in the areas of Shanshan (Piqan), Luntai (Bügür) and Fuhai (Burultokay). Kashgar and Hotan have high rates and birth and mortality. Urumqi, Shihezi, Kuytun, Shanshan and Aksu have a level of population growth under $1 \%$. 
The Xinjiang population structure was altered by the implementation of the "Settlement policy"10 by the government in Beijing. There are two population belts in the north and south that are connected by infrastructure. Recently industrialised cities, such as Urumqi, Shihezi and Korla, replaced traditional urban centres such as Kashgar and Turpan. The population density of rural parts remains higher in Kashgar and Yining. There is a strong regionalization of natural population, with high levels in the south around Kashgar and Hotan and in the north around Yining and Urumqi.

The migration and development of this border region is being set up as a patriotic duty. It is considered that the migration from the 1960s played a major role in the interethnic conflict in Xinjiang. This migration from eastern China changed the population profile. Although the non-Chinese population is now a majority in the region, its scope is not like it was in the early 1940s.

The shown statistics do not reflect realistic demographic movements. HanChinese do not necessarily have to be constantly populated in Xinjiang and tend to live in cities rather than in rural areas, and more in northern than southern parts. Consequently, there are still predominantly Muslim and non-Chinese areas in the west and southwest, which are usually poorer. For example, in Urumqi lives 1,643,760 people, of which $73 \%$ are Chinese, and $12.8 \%$ are Uyghurs, while in the Kashgarian district there are 3,365,560 people, the Chinese make up 8.75\% and Uyghurs $89.7 \%$.

Total Xinjiang population in 1941 was estimated at 3.73 million. From which 80\% were Uyghurs, 8.7\% Kazakhs, 5\% Chinese, 2.5\% Hui Muslims and 1.7\% Kyrgyz. The north was mostly populated by the Kazakhs, south by the Uyghurs. The region around Ili river had approximately equal relation between Uyghurs, Hui Muslims and Kazakhs, while the city of Urumqi was divided between the Chinese and the Uyghurs population.

According to the census documents from 1953, the Uyghurs accounted for 74.7\%, Kazakhs 10\%, Chinese 6\%, Hui Muslims 3\% and Kyrgyz 1.4\%. During the 1950s and 1960s, the migration of people to Xinjiang from the east of the country was supported, especially during the years "Great Leap Forward" $(1958-1961)^{11}$. The Han-Chinese migration took place along the main transport routes. From 1954 until 1961 a total of 1.5 million people migrated to Xinjiang.

10 Beijings' central government policy that supports ethnic balance in all parts of China.

11 The Great Leap Forward was an economic and social plan aimed at harnessing large numbers of people in the country to quickly transform the country from an agricultural economy into a modern industrialized one. The project ended in disaster and triggered one of the deadliest and most severe famines in modern human history in which at least 20 million people have lost their lives (estimates go as high as 40 million) and it makes one of the greatest social disasters of the $20^{\text {th }}$ century (excluding the Second World War). 
During 1959, 800,000 people moved to Xinjiang, and during 1961, as China's economy began to recover, more than 500,000 returned to the home provinces. It was noted that after the incidents in Ili region and Tarbagatay , between 100,000 and 200,000 Kazakhs migrated to the Soviet Kazakhstan. The reasons for leaving were multiple: economic decay of the region, the Han-Chinese migration, the suppression of Islamic Religious practices (and all other religions at the time), and favourable conditions offered by the Soviet Union. A lot of the Uyghurs and Kazakhs received Soviet citizenship at the time. The return during these years was allowed to young offenders from Shanghai who were previously exiled to Xinjiang (Brophy, 2016).

In the territory of Xinjiang, according to the census from 1964, Uyghurs make up 54\%, the Chinese 33\%, Kazakhs 7\%, Hui Muslims 4\%, Kyrgyz 1\% and others constitute $1 \%$ of the population. During the "Cultural Revolution" there was no direct incentive for the migration to Xinjiang. Regardless, in 1967 about 1 million young people moved to Xinjiang, of which a significant part found a job in administration. After the completion of the "Cultural Revolution" 1977, the return migration of rural youth, workers and pensioners were recorded.

At the beginning of 1980s, the new economic politics have layed out the route for new settlers towards Xinjiang. It was permitted that excess rural forces temporarily migrate without prior registration. Thanks to that, farmers with skills in construction, tablecloths, sewing, etc. have become a flotation population, which was not registered in the census. The list of 1982 shows that in Xinjiang lives $46 \%$ of Uyghurs, 40\% Chinese, 7\% Kazakhs, 4\% Hui Muslims and 1\% Kyrgyz. According to that, the share of the Uyghur population has decreased, while the share of Han-Chinese increased. Considering the fertility of Uyghurs was constantly higher than the Chinese, the change of percentage of proportion can only be explained by Chinese migrations from other parts of China.

According to the census in 1990 on the territory of Xinjiang lived 15,156,900 inhabitants, of which $47 \%$ Uyghurs, 38\% Chinese, 7\% Kazakhs, $4.5 \%$ Hui Muslims and 1\% Kyrgyz. Still, the spatial distribution of the population remained similar, and the South was mainly populated by the Uyghurs (except Bayingolin, where there were many Chinese employees). Kazakhs in the north were no longer a majority, while the region around the river Ili was still ethnically colorful, leaving similar national proportions as they were during the Qing Dynasty. During the 1990s, mostly the Han-Chinese inhabited cities of Urumqi, Shihezi and Karamay. Migrants from the east bring their culture, language and customs. Mandarin Chinese becomes lingua franca, replacing Gansu dialect that Chinese spoke in Xinjiang at the beginning of the $20^{\text {th }}$ century. The official politics of 1990s was to develope Xinjiang as quickly as possible, which in this case meant the influx of new migrants from the rest of China (Toops, 2010). 
Table 2. Population and ethnic composition of the Xinjiang in the cities of 1998.

\begin{tabular}{|l|c|c|c|}
\hline City & Population & Uyghurs (\%) & Chinese (\%) \\
\hline Urumqi & 1.391 .896 & 13 & 76 \\
\hline Shihezi & 581.952 & 11 & 95 \\
\hline Aksu & 498.937 & 41 & 58 \\
\hline Hami & 352.929 & 23 & 69 \\
\hline Korla & 331.976 & 29 & 67 \\
\hline Yining & 332.022 & 48 & 36 \\
\hline Kashgar & 311.141 & 81 & 18 \\
\hline Turpan & 242.501 & 71 & 21 \\
\hline
\end{tabular}

Source: Xinjiang Statistical Yearbook, 1998

The 2000 census registers 18,462,600 people in Xinjiang, and according to this data, it is calculated that since 1990 the population annually grew by $1.67 \%$. It is important to highlight that Xinjiang comes in 6 . in the size of the population growth rate in China. Greater population growth have only Tibet, Guizhou, Qinghai, Ningxia and Hainan - all regions that have a significant minority population. In 2000 there were 7,497,700 Han-Chinese or $40.6 \%$ of the total population of Xinjiang, while the population of minority people amounted to $10,964,900$ or $59.4 \%$. A particularly important additional calculation would be the inclusion of a flotant population, i.e. unofficial migrants in the area. It is estimated that their share is around 15\% in regard to the total population, or 2.8 million. The vast majority of migrants belong to the Han-Chinese, and their number increases to 10.3 million, which compared to 10.9 million minorities, approximately equalizes their relationship.

The census in 2010 registered an increase of 3,353,823 inhabitants. Continuous high level of natural population increase is continued with the Uyghur population, to which the state policy of one child does not apply, while the Chinese population growth is mostly caused by migration from other parts of China. After this census, inside ethnic relations remain similar to those shown previously. The total population of Xinjiang is less than $2 \%$ of the inhabitants of China (almost 1.4 billion people). It's, comprising $0.6 \%$ of the Chinese population and two fifths of Muslims in China. Population estimates from 2015 show that around 23.6 million people live in Xinjiang, with no significant changes in the ethnic structure compared to the census from 2010. (http:/ / zsyz.sei.gov.cn/ Show Article.asp? ArticleID=263642). 


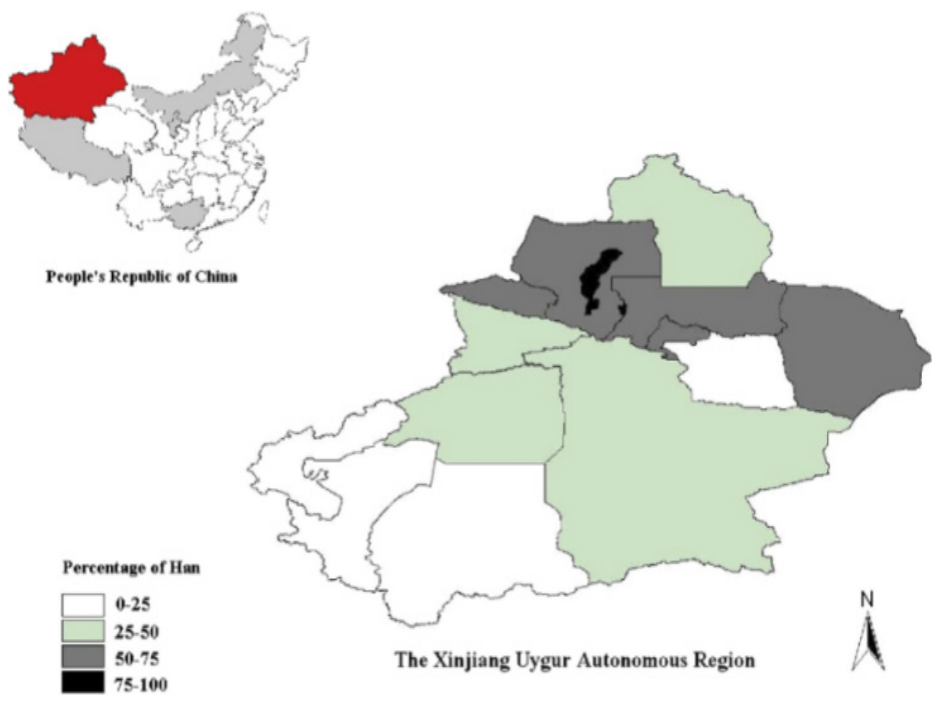

Figure 2. A percentage of Han-Chinese in the Xinjiang 2005

(Source: Xinjiang Statistical Yearbook 2016)

Table 3. The population of Xinjiang, 1941-2010 (in 000)

\begin{tabular}{|c|c|c|c|c|c|c|c|}
\hline Ethnic groups & 1941. & 1953. & 1964. & 1982. & 1990. & 2000. & 2010. \\
\hline Uyghurs & 2.984 & 3.640 & 4.021 & 5.995 & 7.195 & 8.345 & 9.999 \\
\hline Chinese & 187 & 299 & 2.445 & 5.284 & 5.696 & 7.490 & 8.830 \\
\hline Kazakhs & 326 & 492 & 501 & 903 & 1.106 & 1.245 & 1.418 \\
\hline Hui Muslims & 92 & 150 & 271 & 567 & 682 & 840 & 984 \\
\hline Kyrgyz & 65 & 68 & 69 & 112 & 140 & 159 & 164 \\
\hline Others & 76 & 225 & 133 & 220 & 338 & 380 & 419 \\
\hline Total & 3.730 & 4.874 & 7.442 & 13.081 & 15.157 & 18.460 & 21.813 \\
\hline
\end{tabular}

Sources: Qingli, 1990 \& Freeberne 1966 \& Xinjiaang Statistical Yearbook 1996 \&

http:/ / theasiadialogue.com/2016/03/07/ spatial-results-of-the-2010-census-in-xinjiang

\section{Linguistic structure}

Broadly observed, Xinjiang is divided among Muslims, most of which speak Turkic languages, and non-Muslim Han-Chinese. Muslims are a majority, but are not a solid block because they are linguistically and culturally divided (Roberts, 2004). In the explanation of the country's homogeneity in geographical and cultural terms the history of ancient emperors is more important than today's ethnic diversity, their confessionality or other cultural habits (Grčić, 2014). 
Diverse linguistic structure and different letters the people of Xinjiang are using represent the communication barrier and a great integral challenge in the future. The Uyghurs language, as one of the main non-Chinese languages in the region, belongs to the East Althai branch of Turkic languages ${ }^{12}$. The most related are the middle Asian languages, particularly Uzbeks, which some consider the same language of another dialect. Knowledge level of Chinese language among the Uyghurian and Kazakhs elite may be low, even in the dominant Chinese parts of the region such as Urumqi. Also, it's a small number of Chinese that can communicate using Uyghur language.

Since accepting Islam, the Uyghur letter takes the form of an Arab letter. At the beginning of the $20^{\text {th }}$ century Uyghurs did not switch to the Latin alphabet (like the Turks did under Kemal Ataturk, or the Cyrillic variant, as some of the Central Asian people under the influence of the Russians). However, the "new letter" for Uyghurs was created in 1958. By changing the experimental Cyrillic alphabet, the new letter was based on the modified Latin. A modern, Uyghur letter still uses the so-called "old letter", i.e. modified Persian-Arabic variant. All the Uyghurian books, newspaper, names of the streets and shops, appear to this day they in the old letter. Reactivation of the old letter helped the Uyghurs to identify and determine closer to the rest of the Muslim world. In neighbouring Uzbekistan, from 1993 the Cyrillic alphabet was replaced with Latin. According to the forementioned links and closeness of the two languages, in the future different factors may affect the Uyghurs and their decision about "choosing" a new letter.

\section{Conclusion}

A key factor of demographic study is an analysis of the population according to ethnicity. In the case of Xinjiang, the high population growth of the Uyghur population (to which the Chinese government did not limit the number of children), and the migration of Han-Chinese are the dominant factors of demographic analysis. With the rising urbanisation in the future, it is expected that the level of population growth of the Uyghur population will decline. Overall, increasing the number of people in China is slowing down. It is difficult to say with certainty whether the Chinese migration will continue in the future and to what extent. It is certain that the Chinese people have demographic potential and a great opportunity to, regardless of the oscillations of the population in other parts of China, dominate the population of Xinjiang in the future. A part of the new "Silk Road", announced by the Chinese government, should pass through

12 The modern Uyghur language is significantly different from the modern Turkish language. 
this region and may bring improvements in living standards to all. Expected increased circulation of people and capital, could easily alter the ethnic image of the region. It is unknown how many of these processes the central government in Beijing and the Chinese people will want, and on the other hand, if it comes to it - what will be the "defence" capacities of the Uyghur population.

Responses to Islamic extremism and secessionism remain one of the main challenges for the region's future. As Miroljub Jevtic notices (2011): “The Islamic movement has no other ideology but Islam. And the Islam has no dilemma when it comes to the nation and its organisation. For Islam, a nation in ethnic categories does not exist. Islam knows only the religious community of Muslims, regardless of what ethnic nation the Muslims belong to, what language they speak, or which race they are. This is the stance of the traditional Islamic theory, and this is the stance of all the most moderate and most representative Islamic international institutions."

It is more than certain that Chinese authorities are doing everything in order to create favourable conditions for the co-existence of Muslims within a secular Chinese order. However, as Muslims expand a parallel system of values reflected in the unacceptance of any non-Islamic model, the question is what in this respect can China expect from its Muslim minority. Besides, the Hui example shows well what Islamization means. In conditions of living in their home country - China, among its countrypeople who are not Muslims, the Hui no longer declare themselves as Chinese.

\section{References}

Brophy, D. (2016). Uyghur Nation, Reform and Revolution on the Russia - China Frontier. Harward University Press, USA.

Dillon, M. (2004). Xinjiang - China's Muslim Far Northwest, Durham East Asia Series. Department of East Asian Studies, University of Durham, UK.

Fletcher, J. (1968). China and Central Asia, 1368-1884, The Chinese world order: traditional China's foreign relations. Harward University Press, USA.

Freeberne, M. (1966). Demographic and Economic Changes in the Sinkiang Uighur Autonomous Region. Population Studies 20. Routledge, UK.

Maljavin, V. (2008). Kina - Istorija, kultura, religija. NNK Internacional.

Mehta, K. (2018). Locating Xinjiang in China's Eurasian Ambitions. ORF - Observer Research Foundation, India.

Millward, A. J., \& Perdue, C. P. (2004). Political and Cultural History of the Xinjiang Region through the Late Nineteenth Century. Central Asia-Caucasus Institute, USA. 
Qing-li, Y. (1990). Population Changes in Xinjiang Uighur Autonomous Region (19491984). Journal Article - Central Asian Survey. Pergamon press, UK.

Roberts, S. R. (2004). A "Land of Borderlands": Implications of Xinjiang's Trans-border Interactions. The George Washington University, USA.

Soucek, S. (2000). A History of Inner Asia. Cambridge University Press, UK.

Toops, S. (2010). The Demography of Xinjiang, The Xinjiang Uyghur Autonomous Region of China. Routledge, Taylor \& Francis, UK.

Xinjiang Uygur Autonomous Region Bureau of Statistics (1996), Xinjiang Statistical Yearbook, 1997. China Statitstics Press, China.

Xinjiang Uygur Autonomous Region Bureau of Statistics (1999), Xinjiang Statistical Yearbook, 1998. China Statitstics Press, China.

Xinjiang Uygur Autonomous Region Bureau of Statistics (2004), Xinjiang Statistical Yearbook, 2016. China Statitstics Press, China.

Грчић, М. (2014). Географија култура и цииилизација. Универзитет у Београду Географски факултет.

Јевтић, М. (2011). Исламски екстремизам као облик угрожавања Кине. Факултет политичких наука, Београд, Србија.

www.thebetter.wiki/en/Tarim_Basin

www.zsyz.sei.gov.cn/ShowArticle.asp?ArticleID=263642

www.theasiadialogue.com/2016/03/07/spatial-results-of-the-2010-census-inxinjiang 